\title{
A Histological and Histochemical Study on the Gallbladder of the Alburnus tarichi (Güldenstädt, 1814) (Cyprinidae)
}

\author{
Estudio Histológico e Histoquímico de la Vesícula Biliar \\ de Alburnus tarichi (Güldenstädt, 1814) (Cyprinidae)
}

Burak Kaptaner'; Handan Aykut² \& Emine Dogan²

KAPTANER, B.; AYKUT, H. \& DOGAN, E. A histological and histochemical study on the gallbladder of the Alburnus tarichi (Güldenstädt, 1814) (Cyprinidae). Int. J. Morphol., 38(4):869-875, 2020.

SUMMARY: In the current study, the histological structure of the gallbladder of Alburnus tarichi (Güldenstädt, 1814) was investigated. Hematoxylin and eosin were used to stain the histological sections for routine examinations, in addition to using periodic acid Schiff (PAS) for the neutral mucins, aldehyde fuchsin (AF) for the sulphated mucins, and Alcian blue (AB; $\mathrm{pH}$ : 2.5) for the acidic mucins. In addition, proliferating cell nuclear antigen (PCNA) immune-staining was performed for the detection of dividing cells among the epithelium. The gallbladder of A. tarichi was composed of mucosa, muscularis, and serosa or adventitia layers. The mucosa covering the wavy pleomorphic folds was made up of tall columnar epithelium and a lamina propria. The apical surface of the epithelial cells was lined by continuous short microvilli. On the epithelium, the luminal surface was remarkably stained with PAS, AF, and AB. Slight to moderate staining was observed on the epithelial cells in the apical zone with PAS. The cytoplasm of epithelial cells were stained in a slight manner with AF. No goblet cells were observed among the epithelium. According to the PCNA immune-staining, some epithelial cells were observed to proliferate. The lamina propria consisted of loose connective tissue that contained fibrocytes, collagen and elastic fibers, capillaries, and small blood vessels. The muscularis layer displayed muscle fibers that were circular, smooth, and surrounded by collagen fibers. The subserosal and serosal or adventitial layers had typical morphology to those of other fish and vertebrates.

KEY WORDS: Gallbladder; Alburnus tarichi; Fish; Histology; Histochemistry; PCNA.

\section{INTRODUCTION}

Gallbladder carries out 2 main functions, in the case of an animal, that first is storing bile and concentrating bileabsorbing water and electrolytes (sodium chloride, $\mathrm{HCO}_{3}$ ) by its mucosa. The second is secreting concentrated bile into intestine via smooth muscle contraction and assisting of absorption of lipid soluble compounds (Banfield 1975). Among its other functions, the gallbladder epithelium is responsible for the secretion and excretion of substances like hormones and xenobiotics. Additionally, it produces and secrets mucus as a protective film layer at the surface of gallbladder and some parts of bile tract (Oldham-Ott \& Gilloteaux, 1997). Accordingly, a variety of studies on gallbladder mucins have been performed using histochemistry in mammalian species and showed their possible pathophysiological roles on cholelithogenesis (Madrid et al., 1997; Gilloteaux, 1997).

Despite the presence of several histological and histochemical studies on gallbladder in various fish species
(Togari \& Okada, 1960; Viehberger, 1982; Madrid et al., 1989; Gillotaux et al., 2011; Gillotaux et al., 2013), they are quantitatively inadequate, because fish are a diversified group of animals that can be categorized into 3 different classes: Agnatha or Cyclostomata, Chondrichthyes, and Osteichthyes. Moreover, the diet of fish varies depending on their feeding habitat and niche adaptation. Those factors also affect digestive system morphology and its accessory organ gallbladder between classes (Oldham-Ott \& Gilloteaux). Therefore, more histological and histochemical investigations are necessary to elucidate the gallbladder among different fish species.

Alburnus tarichi (Güldenstädt, 1814) is an anadromous Cyprinid species endemic to the Lake Van basin of Turkey. Lake Van is the Earth's largest soda lake and it has highly alkaline (total alkalinity of $153 \mathrm{meq} / \mathrm{L} ; \mathrm{pH} 9.8$ ) and brackish (total salinity of $0.22 \%$ ) water. The lake exhibits an extreme living environment. The littoral zone displays

\footnotetext{
${ }^{1}$ Department of Biology, Faculty of Science, University of Van Yuzuncu Yil, Tusba, Van, Turkey.

${ }^{2}$ Department of Biology, Institute of Natural and Applied Sciences, University of Van Yuzuncu Yil, Tusba, Van, Turkey.
} 
an absence of higher plants and the living conditions are generally lethal for other fish and invertebrates. However, A. tarichi has physiological abilities allowing it to adapt to the lake's harsh conditions (Danulat \& Selcuk, 1992). However, to date, no study regarding histological organization and histochemical features of gallbladder in $A$. tarichi has been performed. In the present study, it was aimed to understand the microscopic anatomy of the gallbladder in this endemic species and learn how they differed from other fish species. Those results were reported herein for the first time, and will provide reference knowledge for future studies of A. tarichi.

\section{MATERIAL AND METHOD}

Fish. Herein, 8 adult Lake Van fish (Alburnus tarichi Güldenstädt, 1814), with a fork length of 18 to $20 \mathrm{~cm}$ and total weight of between 80 and $100 \mathrm{~g}$, were examined. The fish used as the study material were caught by professional fishermen, during the fishing season in November, 2019, in Lake Van $\left(43^{\circ} 13^{\prime} \mathrm{E}, 38^{\circ} 26^{\prime} \mathrm{N}\right)$. The deaths of the fish were the result of natural causes. Therefore, in accordance with the Turkish Ministry of Forestry and Water Affairs regulations, the use of animal tissue post mortem did not require Animal Experiments Local Ethics Committee approval (The Official Gazette of Republic of Turkey on February 15, 2014, No: 28914); however, a decision protocol was issued by the above mentioned Ethics Committee of Van Yuzuncu Yil University (VAN YUHADYEK) under decision number: YUHADYEK-2019/10, protocol number: 27552122-604.01.02-E.86004.

Histological procedures. Immediately after the death of the animals, careful dissection of the gallbladder and its annex tissues was performed. Next, Bouin's solution, in addition to a concentration of neutral buffered formalin (10 $\%$ ), separately, was used to fix the tissues at $4{ }^{\circ} \mathrm{C}$ for $24 \mathrm{~h}$. After which, a graduated ethanol series was used to dehydrate the tissues, and these were embedded in paraffin. As a next step, 5 - $\mu$ m-thick cross-sections of the tissues were taken and then placed on slides coated with adhesive (Marienfeld GmbH, Lauda-Königshofen, Germany). Following deparaffinization and rehydration, hematoxylin and eosin (H\&E) was used to stain the tissue sections for the routine histological examinations, while Mallory's triple (Crossmon, 1937) was used for the collagen fibers; periodic acid-Schiff (PAS) (McManus, 1948) was used for the neutral mucins, sialomucins, and glycogen; aldehyde fuchsin (AF), as described by Lamar Jones (2002), was used for the sulphated mucins and elastic fibers; and Alcian blue $(\mathrm{AB})$ at $\mathrm{pH} 2.5$, according to Totty (2002), was used for the acidic mucins.
In some of the sections, counterstaining was performed for the PAS staining with Mayer's hematoxylin and for the AF or $\mathrm{AB}$ staining, neutral red was used. Figures for both the counterstained and uncounterstained sections stained with PAS, AF, and AB were presented in the Results section for comparison. Canada balsam was used to mount all of the preparations, and a Leica DMI 6000B microscope (Leica Microsystems, Wetzlar, Germany) was used to examine and photograph them. The heights and widths of the epithelial cells of the gallbladder were measured using ImageJ 1.46 software (https://imagej.nih.gov/ij/download.html).

PCNA immunohistochemistry. For detection of proliferating cells in the epithelial layer immunohistochemical proliferating cell nuclear antigen (PCNA) staining was conducted. The sections of the neutral buffered formalin-fixed tissues were then deparaffinized, rehydrated, and incubated for 10 min with $3 \%$ hydrogen peroxide to prevent endogenous peroxidase activity. Trisbuffered saline (TBS) (20 mM Tris and $140 \mathrm{mM} \mathrm{NaCl}$ ) at a $\mathrm{pH}$ of 7.6 was used for washing the sections, followed by the application of a protein block for $10 \mathrm{~min}$ to inhibit nonspecific binding. The sections were then incubated with primary antibody (a mouse monoclonal PC10 to PCNA, cat. number: ab29, Abcam plc., Cambridge, UK) at a dilution of 1:200 overnight. After the sections had been washed with TBS, the remaining procedures were performed using the EXPOSE mouse and rabbit specific IHC/DAB detection IHC kit (cat. no: ab80436; Abcam, UK), following the manufacturer's instructions, as described by Ceylan \& Kaptaner (2019). To perform the counterstaining, Mayer's hematoxylin was used. Next, the slides were rinsed in graded ethanol concentrations (95\% and $100 \%$ ) and xylene, and Canada balsam was used to seal them (Merck, KGaA, Darmstadt, Germany). To test the antibodies' specificities, negative control slides were used, to which TBS was added in place of the primary antibody. A Leica DMI 6000B microscope was used to perform the examinations and take photographs of the slides.

\section{RESULTS}

The gallbladder is located under the anterior portion of right liver lobe. It is spheroid to ellipsoid in shape and yellow to greenish in color. Approximately, two-thirds of the gallbladder is surrounded by adipose tissue containing pancreatic tissues (Fig. 1A). The gallbladder is composed of 3 layers, including the mucosa, muscularis, and serosa or adventitia. The mucosa covering the wavy pleomorphic folds is made up an epithelium lining the inner surface and a lamina propria, which lies beneath the epithelial layer (Figs. 

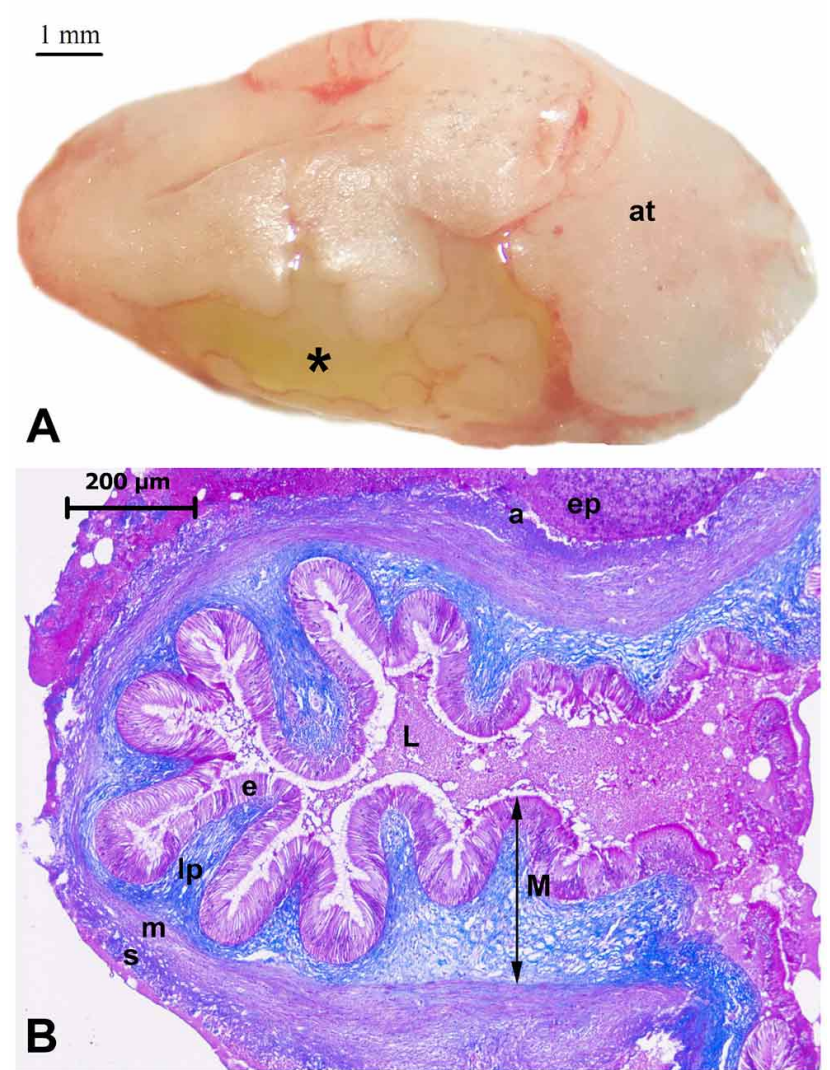

Fig. 1. A) Photograph of the dissected gallbladder of A. tarichi surrounded by adipose tissue (at) containing pancreatic tissues. Asterisks on the gallbladder display free surface. B) Cross-section of the gallbladder stained with Mallory's triple displaying the typical layers and adjacent tissue (a: adventitia; e: epithelium; ep: exocrine pancreas; L: lumen; lp: lamina propria; m: muscularis; M: mucosa; s: serosa).

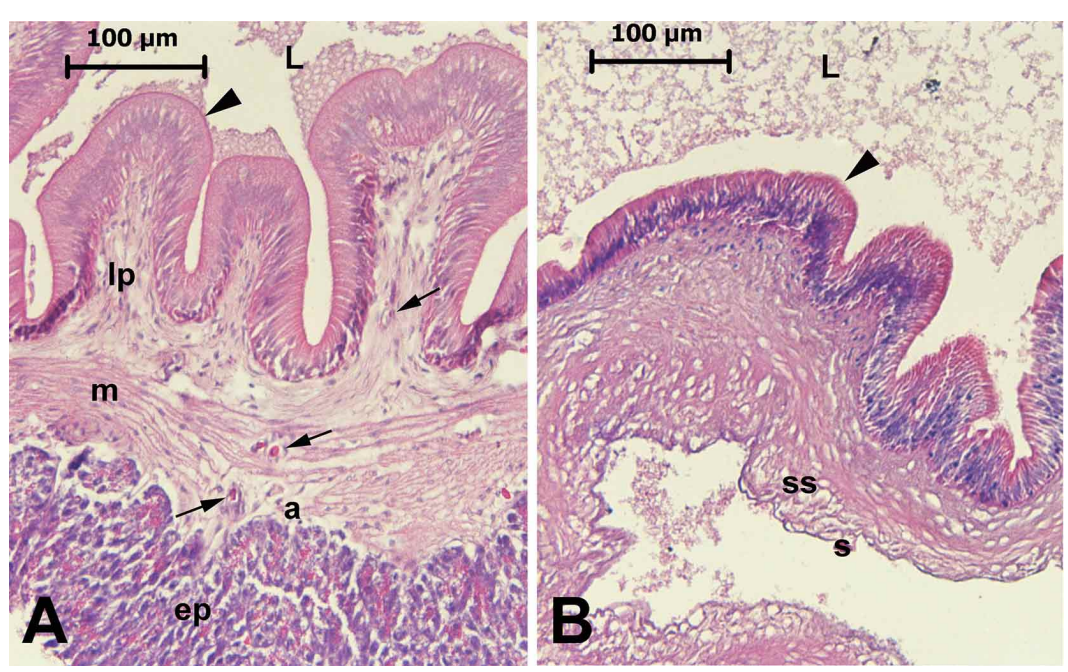

Fig. 2. Cross-sections from the attached (A) and free (B) surfaces of the gallbladder wall stained with H\&E. The apical surface of the epithelial cells was lined by short microvilli (arrowheads). An area of the exocrine pancreas (ep) in the attached surface and serosa (s) and subserosa (ss) in the free surface can be seen. Some capillaries are indicated with arrows among the lamina propRia (lp), muscularis (m), and adventitia (a).
$1 \mathrm{~B}$ and 2). The prominent oval nuclei of the epithelial cells are located basally or close to the basal region. The apical surface of those cells was covered by a margin of short microvilli. Goblet cells were not determined among the epithelial layer (Figs. 2A-B). The epithelium of the gallbladder was arranged as tall columnar cells ranging from 16.76 to $73.80 \mu \mathrm{m}$ and averagely measuring $44.03 \mu \mathrm{m}$ in height and from 1.83-6.29 to $3.22 \mu \mathrm{m}$ in width, which were and located on basal membrane. The positively immunestained proliferating cells in their nuclei with PCNA were observed among the epithelium (Fig. 3). Loose connective tissue was observed in the lamina propria, which comprised fibrocytes, collagen, and AF-stained elastic fibers, and

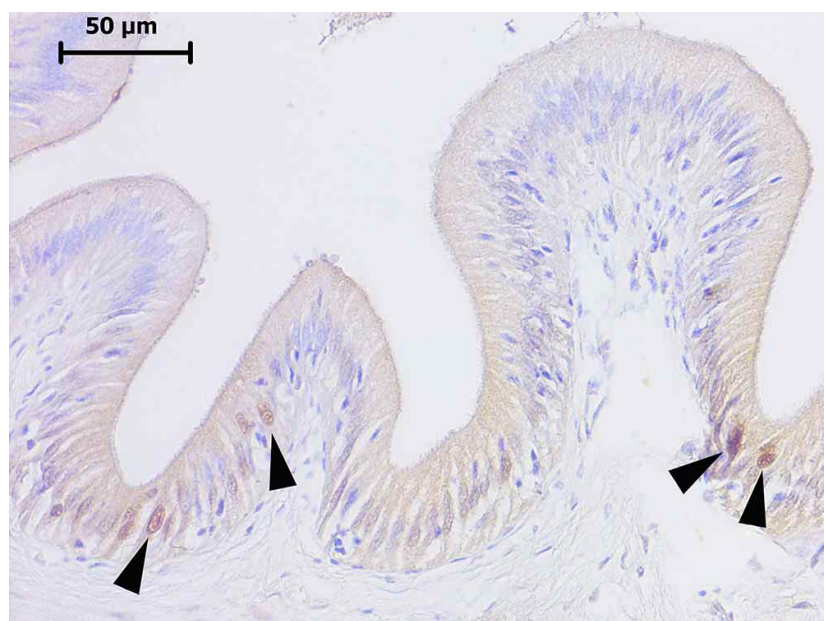

Fig. 3. Proliferating cells (arrowheads) containing nuclei that were stained brown and detected via PCNA immunohistochemistry in the epithelial layer of the gallbladder of A. tarichi.

capillaries, usually including erythrocytes and in a few extent small blood vessels (Figs. 2A, 4 and 6). The muscularis was comprised of circular muscle fibers surrounded by collagen fibers and was invaded by a few capillaries (Figs. 2A and 4). The outermost serosa layer of the free surface of the gallbladder was covered by a mesothelium and made up of a thin subserosal loose connective tissue containing collagen fibers and occasionally determined small vessels (Fig. 2B). The surface of the gallbladder adjacent to the adipose tissue or pancreas included an adventitial layer comprised of loose connective tissue, including collagen fibers, capillaries, and blood vessels (Figs. $2 \mathrm{~A}$ and 4 ).

The luminal surface of the epithelial cells showed a remarkable 


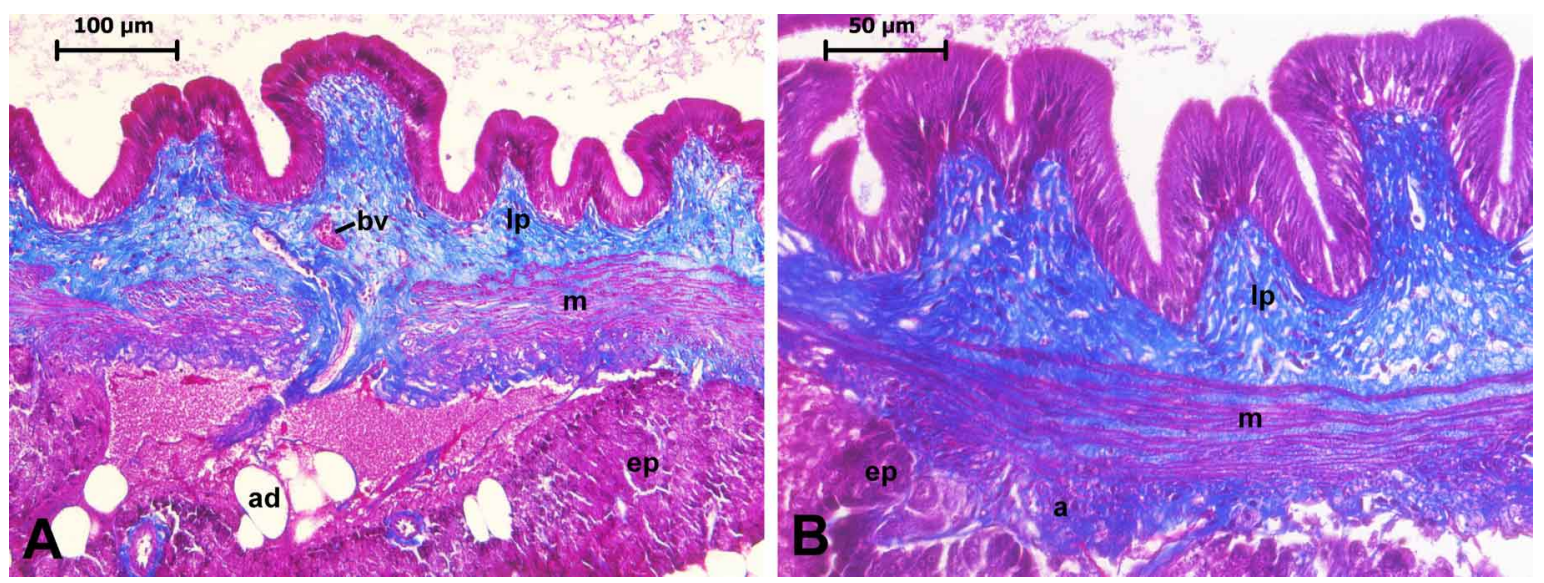

Fig. 4. Mallory's triple staining in the gallbladder wall of $A$. tarichi at different magnifications; $20 \times(\mathrm{A})$ and $40 \times(\mathrm{B})$. Collagen fibers stained in blue throughout the loose connective tissue of the lamina propria (lp), and among the muscle fibers of the muscularis ( $\mathrm{m}$ ) and in the adventitia (ad) can be seen. Blood vessels (bv) were found in lamina propria and adipocytes (ad), and exocrine pancreas (ep) tissue was observed in the outer surface of the gallbladder.

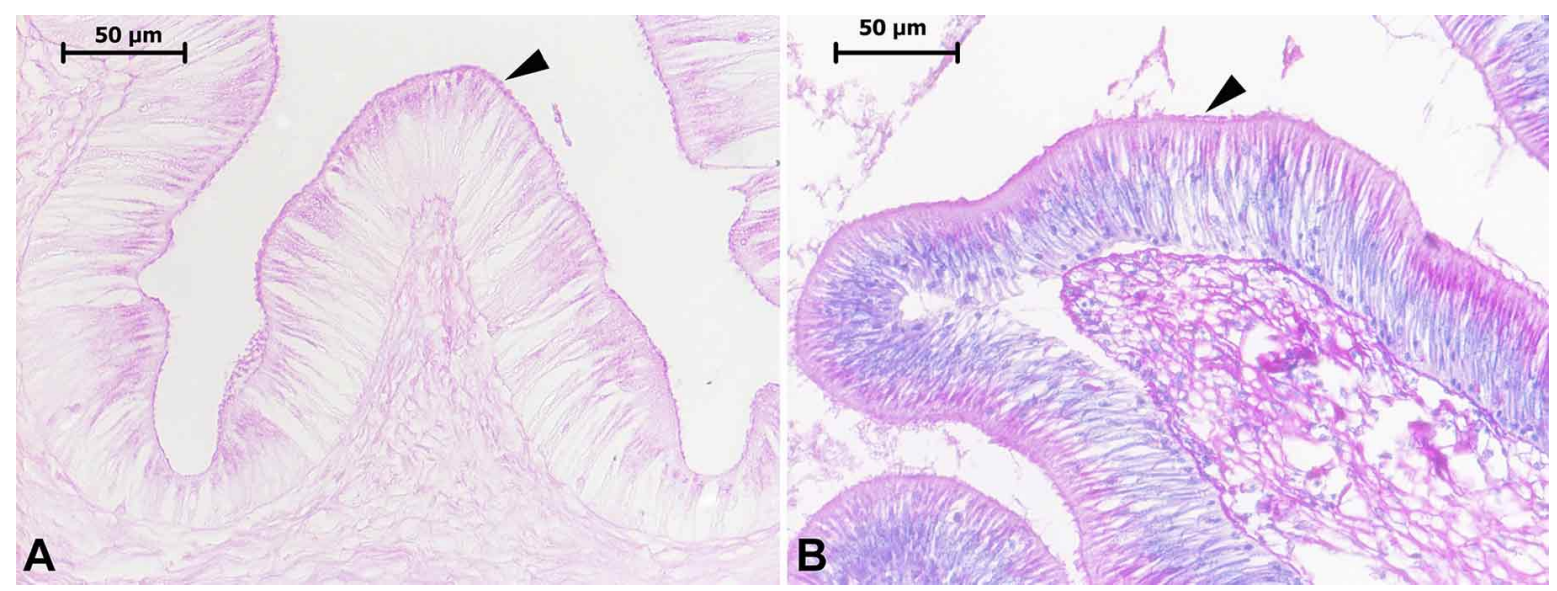

Fig. 5. PAS staining without counterstaining (A) and with counterstaining using Mayer's hematoxylin (B) in the gallbladder sections. A remarkable staining with PAS was observed on the luminal surface of the epithelial layer (arrowheads). PAS reaction was also found in the apical zone of the epithelial cells.
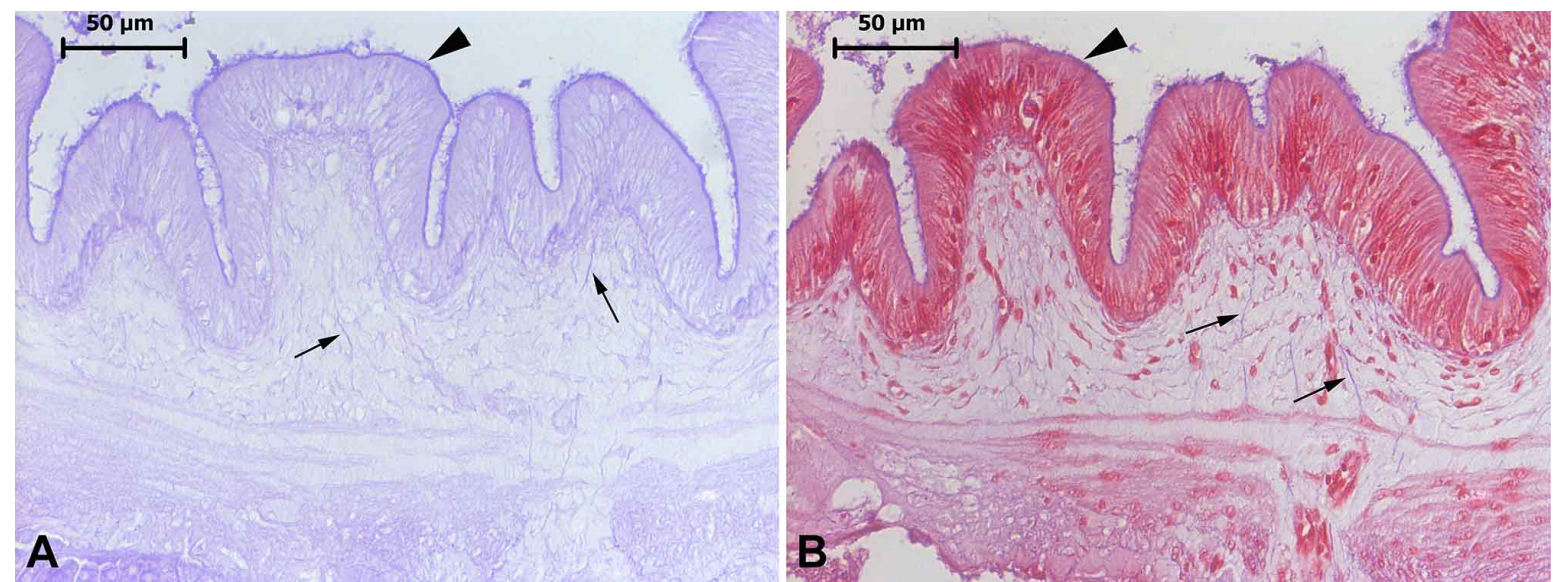

Fig. 6. AF staining without counterstaining (A) and with counterstaining using neutral red (B) in the gallbladder sections. A remarkable reaction with $\mathrm{AF}$ was observed at the luminal surface of the epithelial layer (arrowheads). Weak reaction was also observed in the cytoplasmic zone of the epithelial cells. AF-stained elastic fibers (arrows) were also identified in the lamina propria. 
positive histochemical reactivity by PAS staining, indicating the presence of neutral mucins, sialomucins, and glycogen. Slight to moderate luminal surface PAS reactivity was also detected at the apical zone of the epithelial cells (Figs. 5 AB). AF staining for sulphated groups was detected in the luminal surface of the epithelial cells. In addition, the cytoplasm showed a slight staining with AF (Figs. 6A-B). $\mathrm{AB}$ histochemical staining for acidic mucopolysaccharides was restricted to the luminal surface of the epithelial layer (Figs. 7A-B).

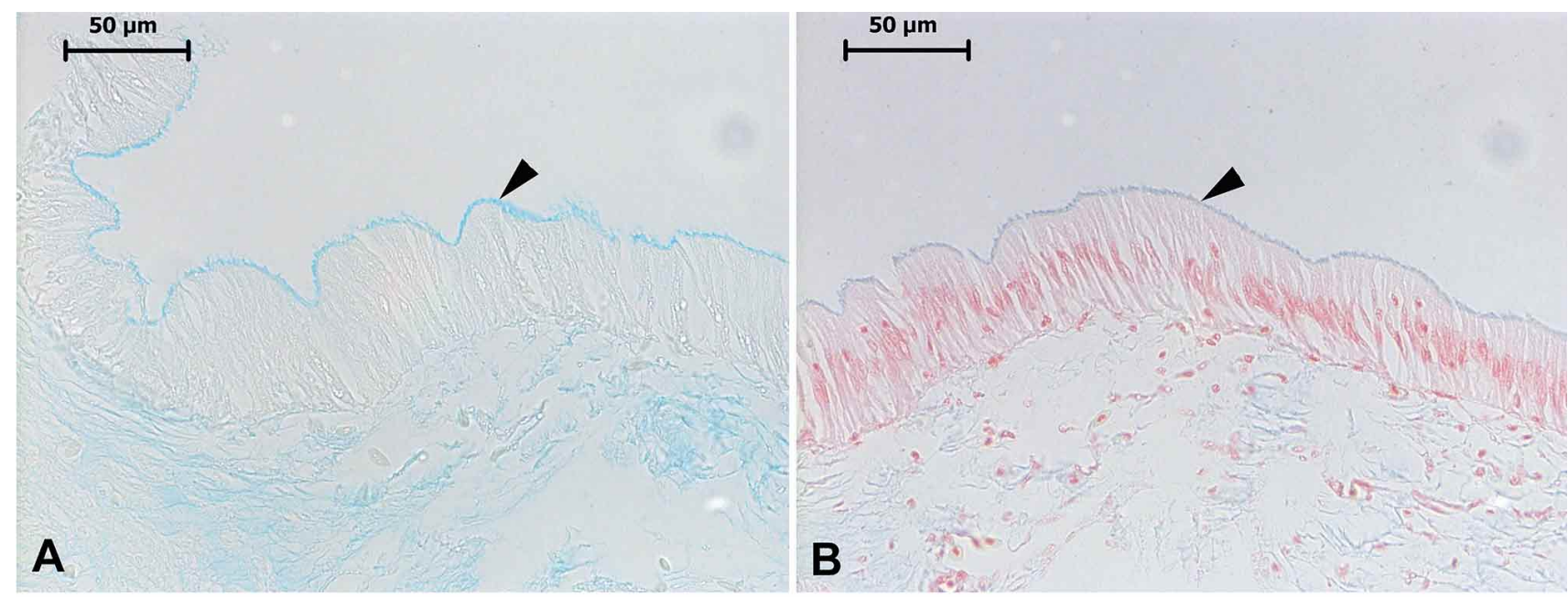

Fig. 7. AB staining without counterstaining (A) and with counterstaining using neutral red (B) in the gallbladder sections. A remarkable reaction with $\mathrm{AB}$ was observed at the luminal surface of the epithelial layer (arrowheads). No cytoplasmic staining was found in the epithelial cells.

\section{DISCUSSION}

The histological layers of the gallbladder wall were composed of mucosa including surface epithelium and lamina propria, circular smooth muscle, and serosa. Those layers are also present in other fish species (Western, 1969; Gupta, 1971; Gilloteaux et al., 2011, 2013; Nazlic et al., 2014) and in agreement with other vertebrates and mammals (Oldham-Ott \& Gilloteaux; Mobini \& Poursafar, 2019). The surface epithelium lining the mucosal folds thrown into the lumen of the gallbladder is comprised of tall columnar cells. Togari \& Okada also reported single-layered high columnar cells in the gallbladder of the different fish species, such as sweetfish (Plecoglessus altivelis), rainbow trout (Salmo irideus), snake head fish (Chana argus), catfish (Parasilurus asotus), loach (Misgurnus anguillicaudatus), chub (Ganathopogon elongates), and Zacco platypus, whereas they observed pseudostratified epithelium scattered as islets in a single epithelial layer of some other fish species, such as carp (Cyprinus carpio), gibel (Carassius auratus), dace (Leuciscus hakonensis), Zacco temminckii, and Acheilongnathus moriokae. Cholecystocytes were also arranged as simple columnar epithelium in the gallbladders of stargazer (Uranoscopus scaber) (Gilloteaux et al., 2011) and Torpedo marmorata (Gilloteaux et al., 2013). The heights and widths of the mucosal epithelial cells of the gallbladder can markedly vary depending on the fish species.
The heights of the epithelial cells were averagely measured as $60 \mu \mathrm{m}$ in Cyprinus carpio, $50 \mu \mathrm{m}$ in Carassius auratus, $45 \mu \mathrm{m}$ Leuciscus hakonensis and Leuciscus hakonensis, 40 $\mu \mathrm{m}$ in Salmo irideus and Parasilurus asotus, $35 \mu \mathrm{m}$ in Chana argus, $32 \mu \mathrm{m}$ in Zacco platypus, $28 \mu \mathrm{m}$ in Misgurnus anguillicaudatus, $25 \mu \mathrm{m}$ in Zacco temminckii, and $16 \mu \mathrm{m}$ in Plecoglessus altivelis (Togari \& Okada). In the gallbladder, the mucosa epithelial cells of the stargazer of Uranoscopus scaber ranged from 50 to $85 \mu \mathrm{m}$ high and were $\leq 5 \mu \mathrm{m}$ wide (Gilloteaux et al., 2011), and ranged from 25 to $45 \mu \mathrm{m}$ high and from 4 to 5 wide for Torpedo marmorata (Gilloteaux et al., 2013). Thus, it can be said that the heights of the mucosal epithelium cells in $A$. tarichi displayed similarities to other fish species, but mainly to Cyprinid species. The apical surface of the gallbladder epithelial cells was observed as lined by a margin of continuous microvilli in A tarichi. In accordance with this study, similar findings have been reported in different studies conducted on different fish species (Western; Viehberger; Gilloteaux et al., 2011, 2013). No goblet cells were observed among the gallbladder epithelium in the present study. The presence of goblet cells among the gallbladder epithelium may display differences between fish species. Although goblet cells have been reported in some fish, they have not been reported in others (Togari \& Okada), as in the current study. 
PCNA, or cyclin, is a protein with multifunctional properties that, in the dividing cells, is highly expressed in phases G1 and S (Kelman, 1997; Kaptaner \& Kankaya, 2013; Ceylan \& Kaptaner). Immunohistochemical analysis of the PCNA supplied important information for evaluating proliferating cells among the gallbladder epithelial cells of $A$. tarichi and some cells displayed positive immune staining in their nuclei. Consistently, Togari \& Okada also observed mitotic divisions in the gallbladder epithelium of different fish species, especially in Cyrinus carpio. The gallbladder epithelium exhibited repairing or reactive cell growth in the some damaged regions in Torpedo marmorata (Gilloteaux et al., 2011). Thus, it can be concluded that epithelial cell renewal is a common observation in the gallbladder epithelium of fish species.

The luminal surface of the gallbladder epithelium exhibited remarkable PAS staining, which indicates neutral mucins, whereas apical zones of the cells were only slightly stained. On the other hand, only the luminal surface of the epithelium was stained with $\mathrm{AF}$ and $\mathrm{AB}$, indicating acidic and sulphated groups, respectively. In accordance of our findings, glycogen staining occurred in small amounts in the epithelium of the gallbladder of fish species and was restricted to the basal, apical, or both sides of the nucleus in the cells, depending on the fish species (Togari \& Okada). A similar staining pattern with a small differences was also observed in the gilthead sea bream (Sparus aurata), where only the luminal surfaces of the epithelial cells of the gallbladder reacted with the above mentioned stains (Madrid et al., 1989). Luminal surface staining in the epithelial cells of the gallbladder with PAS and AF was also observed in upper vertebrates, including amphibian, avian, and mammalian species (Madrid et al., 1989; Mobini, 2012; Mobini \& Poursafar). This suggests that mucin secretion on the epithelial surface might be attributed to a protective barrier role against the possible damaging impact of highly concentrated bile salts, such as amphipathic and strong detergents (Dray-Charier et al., 1997; Gilloteaux et al., 2013).

The lamina propria of the mucosa comprised loose connective tissue that contained elastic fibers, collagen fibers, and capillaries, and fibrocytes. This area was surrounded by smooth muscle bundles surrounded by collagen fibers and was invaded by small vessels. The histological features of all of the layers of the gallbladder wall, including outer subserosa and serosa or adventitia, were in agreement with findings obtained from other teleost fish species (Western; Gupta; Gilloteaux et al., 2011; Nazlic et al.).

\section{CONCLUSION}

In conclusion, the histological and histochemical features of the gallbladder were generally consistent with reports to those of other fish species. Differences in the gallbladder structure between fish species are related to diet (Oldham-Ott \& Gilloteaux). Thus, the differences, such as the lack of goblet cells, may have arisen from its diet. To date, there have been no studies on the histological structure and histochemical properties of the gallbladder of A. tarichi. Thus, the findings herein will provide basic knowledge for studies in the future.

KAPTANER, B.; AYKUT, H. \& DOGAN, E. Estudio histológico e histoquímico sobre la vesícula biliar de Alburnus tarichi (Güldenstädt, 1814) (Cyprinidae). Int. J. Morphol., 38(4):869-875, 2020.

RESUMEN: En este estudio, se investigó la estructura histológica de la vesícula biliar de Alburnus tarichi (Güldenstädt, 1814). Las secciones histológicas se tiñeron con Hematoxilina-Eosina para los exámenes de rutina, además de usar el ácido periódico de Schiff (PAS) para las mucinas neutras, aldehído fucsina (FA) para las mucinas sulfatadas y azul alcián $(\mathrm{AB} ; \mathrm{pH}: 2,5)$ para las mucinas ácidas. Además, se realizó una tinción inmune de antígeno nuclear de células proliferativas (PCNA) para la detección de células en división entre el epitelio. La vesícula biliar de A. tarichi estaba compuesta de capas, mucosa, muscular y serosa o adventicia. La mucosa que cubría los pliegues pleomórficos ondulados estaba formada por un epitelio columnar alto y una lámina propia. Se observó una superficie apical de las células epiteliales revestida por microvellosidades cortas y continuas. En el epitelio se observó una tinción importante de la superficie luminal teñida con PAS, FA y AB. Se observó una tinción leve a moderada en las células epiteliales en la zona apical con PAS. El citoplasma de las células epiteliales se tiñó ligeramente con FA. No se observaron células caliciformes entre el epitelio. Según la tinción de PCNA, se observó que proliferaban algunas células epiteliales. La lámina propia consistía en tejido conectivo laxo que contenía fibrocitos, colágeno y fibras elásticas, capilares y pequeños vasos sanguíneos. La capa muscular mostraba fibras musculares circulares, lisas y rodeadas de fibras de colágeno. Las capas subserosas y serosas o adventicias tenían una morfología típica a la de otros peces y vertebrados.

PALABRAS CLAVE: Vesícula biliar; Alburnus tarichi; Pescado; Histología; histoquímica; PCNA.

\section{REFERENCES}

Banfield, W. J. Physiology of the gallbladder. Gastroenterology, 69(3):7707, 1975.

Ceylan, S. \& Kaptaner, B. Apoptosis and cell proliferation in the epithelia of the esophagus and intestine of Alburnus tarichi Güldenstädt, 1814 (Cyprinidae) during migration from highly alkaline and brackish water to fresh water. Eur. Zool. J., 86(1):103-12, 2019. 
Crossmon, G. A modification of Mallory's connective tissue stain with a discussion of the principles involved. Anat. Rec., 69(1):33-8, 1937.

Danulat, E. \& Selcuk, B. Life history and environmental conditions of the anadromous ChalcAlburnus tarichi in the highly alkaline Lake Van, eastern Anatolia, Turkey. Arch. Hydrobiol., 126(1):105-25, 1992.

Dray-Charier, N.; Paul, A.; Combettes, L.; Bouin, M.; Mergey, M.; Balladur, P.; Capeau, J. \& Housset, C. Regulation of mucin secretion in human gallbladder epithelial cells: predominant role of calcium and protein kinase C. Gastroenterology, 112(3):978-90, 1997.

Gilloteaux, J. Introduction to the biliary tract, the gallbladder, and gallstones. Microsc. Res. Tech., 38(6):547-51, 1997.

Gilloteaux, J.; Ott, D. W. \& Oldham-Ott, C. K. The gallbladder of Uranoscopus scaber L. (teleost perciform fish) is lined by specialized cholecystocytes. Anat. Rec. (Hoboken), 294(11):1890-903, 2011.

Gilloteaux, J.; Ott, D. W. \& Oldham-Ott, C. K. The gallbladder of the electric ray Torpedo marmorata Risso displays excrescent cholecystocytes with merocrine and apocrine-like secretions. Anat. Rec. (Hoboken), 296(1):79-95, 2013.

Gupta, O. P. Studies on the morphology, histology and the swallowing mechanism of the digestive tract of a carnivorous fish, Xenentodon cancila (Ham.). Okajimas Folia Anat Jpn., 48(1):29-51, 1971.

Kaptaner, B. \& Kankaya, E. Analysis of germ cell proliferation, apoptosis, and androgenesis in the Lake Van fish (Chalcalburnus tarichi) during testicular development. Fish Physiol. Biochem., 39(6):1165-79, 2013.

Kelman, Z. PCNA: structure, functions and interactions. Oncogene, 14(6):629-40, 1997.

Lamar Jones, M. Connective Tissues and Stains. In: Bancroft, J. D. (Ed.). The Theory and Practice of Histological Techniques. $5^{\text {th }}$ ed. Edinburgh, Churchill Livingstone, 2002. pp.139-62.

Madrid, J. F.; Ballesta, J.; Galera, T.; Castells, M. T. \& Pérez-Tomás, R. Histochemistry of glycoconjugates in the gallbladder epithelium of ten animal species. Histochemistry, 91(5):437-43, 1989.

Madrid, J. F.; Hernández, F. \& Ballesta, J. Characterization of glycoproteins in the epithelial cells of human and other mammalian gallbladder. A review. Microsc. Res. Tech., 38(6):616-30, 1997.

McManus, J. F. Histological and histochemical uses of periodic acid. Stain Technol., 23(3):99-108, 1948.

Mobini, B. \& Poursafar, M. Histological and histochemical studies of the gall bladder of the graylag goose (Anser anser). Biotech. Histochem., 94(6):404-9, 2019.

Mobini, B. Microscopic study of the gall bladder of the chukar partridge (Alectoris chukar). Bulg. J. Vet. Med., 15(2):73-8, 2012.

Nazlic, M.; Paladin, A. \& Bocina, I. Histology of the digestive system of the black scorpionfish Scorpaena porcus L. Acta Adriat., 55(1):65-74, 2014.

Oldham-Ott, C. K. \& Gilloteaux, J. Comparative morphology of the gallbladder and biliary tract in vertebrates: variation in structure, homology in function and gallstones. Microsc. Res. Tech., 38(6):57197, 1997.

Togari, C. \& Okada, T. Cytological studies of the gallbladder epithelium of the fish. Okajimas Folia Anat. Jpn., 35(1-3):11-25, 1960.

Totty, B. A. Mucins. In: Bancroft, J. D. (Ed.), The Theory and Practice of Histological Techniques. $5^{\text {th }}$ ed. Edinburgh, Churchill Livingstone, 2002. pp.163-200.

Viehberger, G. Apical surface of the epithelial cells in the gallbladder of the rainbow trout and the tench. Cell Tissue Res., 224(2):449-54, 1982.

Western, J. R. Studies on the diet, feeding mechanism and alimentary tract in two closely related teleosts, the freshwater Cottus gobio L. and the marine Parenophrys bubalis euphrasen. Acta Zool., 50(3):185-205, 1969.

\author{
Corresponding author: \\ Burak Kaptaner \\ University of Van Yuzuncu Yil \\ Faculty of Science \\ Department of Biology \\ 65080 Tusba \\ Van \\ TURKEY
}

ORCID: B. Kaptaner (http://orcid.org/0000-0003-2366-6756)

\author{
Email: bkaptaner@yahoo.com, bkaptaner@yyu.edu.tr
}

Received: 07-01-2020

Accepted: $17-02-2020$ 